\title{
Correction to: CANPMR syndrome and chromosome 1p32-p31 deletion syndrome coexist in two related individuals affected by simultaneous haplo-insufficiency of CAMTA 1 and NFIA genes
}

Emanuele G. Coci ${ }^{1 *}$, Udo Koehler ${ }^{2}$, Thomas Liehr ${ }^{3}$, Armin Stelzner ${ }^{1}$, Christian Fink ${ }^{4}$, Hendrik Langen ${ }^{1}$ and Joachim Riedel ${ }^{1}$

\section{Correction to: Molecular Cytogenetics (2016) 9:10} https://doi.org/10.1186/s13039-016-0219-y

Following publication of the original article [1], an error was identified in the article title: the gene name NFIA was incorrectly captured as NIFA. The article title has been updated above and in the original article.

\section{Author details}

${ }^{1}$ Center of Social Pediatrics and Pediatric Neurology, General Hospital of Celle, 29221 Celle, Germany. ${ }^{2}$ Medizinisch Genetisches Zentrum, 80335 Munich, Germany. ${ }^{3}$ Institute of Human Genetics, Friedrich Schiller University, Jena University Hospital, 07743 Jena, Germany. ${ }^{4}$ Department of Radiology, General Hospital of Celle, 29223 Celle, Germany.

Published online: 09 March 2021

\section{References}

1. Coci EC, et al. CANPMR syndrome and chromosome 1p32-p31 deletion syndrome coexist in two related individuals affected by simultaneous haplo-insufficiency of CAMTA1 and NFIA genes. Mol Cytogenet. 2016;9:10. https://doi.org/10.1186/s13039-016-0219-y.

The original article can be found online at https://doi.org/10.1186/s1303 9-016-0219-y.

*Correspondence: Emanuele.Coci@akh-celle.de

${ }^{1}$ Center of Social Pediatrics and Pediatric Neurology, General Hospital of Celle, 29221 Celle, Germany

Full list of author information is available at the end of the article

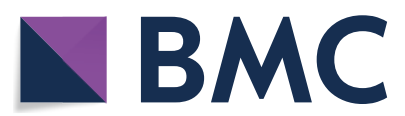

(c) The Author(s) 2021. This article is licensed under a Creative Commons Attribution 4.0 International License, which permits use, sharing, adaptation, distribution and reproduction in any medium or format, as long as you give appropriate credit to the original author(s) and the source, provide a link to the Creative Commons licence, and indicate if changes were made. The images or other third party material in this article are included in the article's Creative Commons licence, unless indicated otherwise in a credit line to the material. If material is not included in the article's Creative Commons licence and your intended use is not permitted by statutory regulation or exceeds the permitted use, you will need to obtain permission directly from the copyright holder. To view a copy of this licence, visit http://creativecommons.org/licenses/by/4.0/. The Creative Commons Public Domain Dedication waiver (http://creativecommons.org/publicdomain/zero/1.0/) applies to the data made available in this article, unless otherwise stated in a credit line to the data.

\author{
Publisher's Note \\ Springer Nature remains neutral with regard to jurisdictional claims in pub- \\ lished maps and institutional affiliations.
}

